Environment Conservation Journal 15(3) 41-46, 2014

ISSN 0972-3099 (Print) 2278-5124 (Online)

Abstracted and Indexed

\title{
Length-weight relationship and condition factor of brown trout (Salmo trutta fario L.) from River Asiganga, Uttarakhand (India)
}

\author{
M.S. Rawat, Babita Bantwan, Dhyal Singh and O.P. Gusain $\bowtie$
}

Received:15.09.2014

Accepted: 12.11.2014

\begin{abstract}
The present study was performed to describe length-weight relationship of ecological and commercial important exotic fish brown trout (Salmo trutta fario L.) inhabited in River Asiganga, a tributary of River Bhagirathi. The knowing of length-weight relationship is important because it provides information on the life history of species and an input to the assessment of fishery resource of the region. The length-weight relationship was estimated as: $\log \mathrm{W}=0.310+3.096 \mathrm{Log}$ $L$ for males, $\log W=0.291+3.040 \mathrm{Log} L$ for females and $\log W=0.302+3.073 \mathrm{Log} L$ for overall. The coefficient of correlation ( $r$ ) for the length-weight relationship was estimated 0.985 which showed a high degree of positive correlation between the length and weight of the fish. The condition factor $(K)$ value was estimated highest $1.473 \pm 0.694$ for the male and $1.357 \pm 0.210$ for the female sex during winter.
\end{abstract}

Keywords: Asiganga, brown trout, condition factor, Length-weight relationship

\section{Introduction}

The length-weight relationship is a very useful tool in fisheries assessment. It is usually easier to measure length than weight and weight can be predicted later on using the length-weight relationship. Furthermore, standing crop biomass can be estimated (Morey et al., 2003) and seasonal variations in fish growth can be tracked in this way (Richter et al., 2000). The length-weight relationship helps in predicting the condition, reproductive history and life history of fish species (Nikolsky, 1963; Wootton, 1992; Pauly, 1993) and in morphological comparison of species and populations (King, 1995; Goncalves et al., 1997). According to Lawson (2011) the investigation on the length-weight relationship studies is important in managing and conserving fish species in habitat. Meanwhile, the condition factors $(\mathrm{K})$ of fish are actually considering the general well being and health of a fish in relation to environment. Brown trout (S. trutta fario L.) is an important game fish and is also preferred food by many due to its taste and high protein value. Brown trout belonging to Author's Address

${ }^{1}$ Department of Zoology, Govt. P.G. College, Doiwala, Dehradun

${ }^{2}$ Department of Zoology \& Biotechnology, HNB Garhwal University Srinagar-Garhwal

E-mail:drmsrawat2@yahoo.co.in family Salmonidae was initially introduced to suitable waters elsewhere for its sporting qualities (Moss, 1998). While, it was introduced in India in early part of the $19^{\text {th }}$ century, mainly to provide an amateur sports fishery and delicious food. However, in Garhwal Himalayan region of Uttarakhand, brown trout was introduced in 1910. Even after a hundred year history in Garhwal scientific information on brown trout (Salmo trutta fario L.) is lacking. For the first time Rawat et al. (2011) documented the status of brown trout (Salmo trutta fario L.) in Garhwal Himalaya. The objective of present study was to provide baseline data on the length-weight relationship and condition factor of brown trout from River Asiganga in Uttarakhand (Fig. 1).

\section{Materials and Methods}

A total of 253 specimens were studied for assessing length-weight relationship and condition factor during August 2007 and July 2009. After removing moisture from the body, measurements of fish length and weight were taken. The total length $(\mathrm{cm})$ and weight $(\mathrm{g})$ was measured for each individual fish. Season-wise the length-weight relationship of males and females was analyzed separately. 


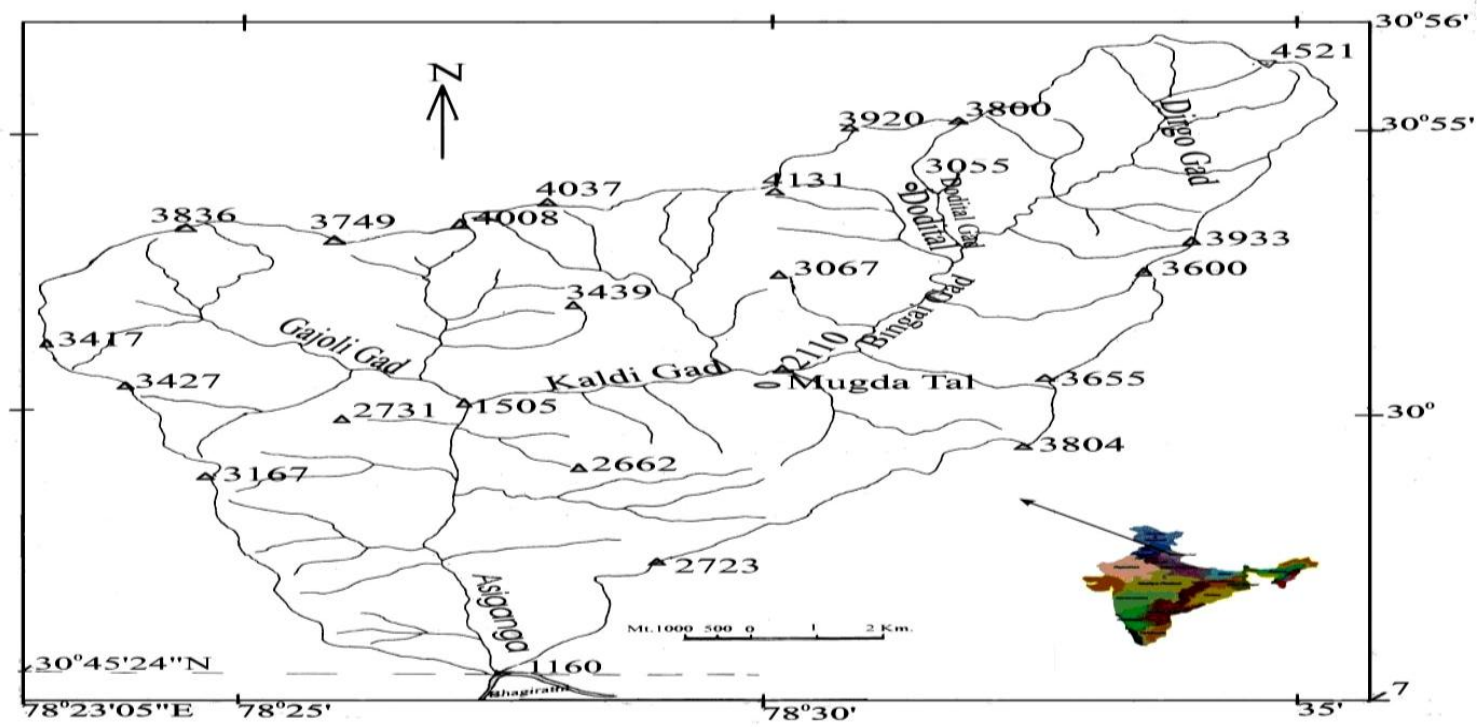

Figure 1. Location map of River Asiganga.

The equation for the length-weight relationship was computed by using the formula for general parabola $\mathrm{W}=\mathrm{aL}^{\mathrm{b}}$ and in the logarithmic form $\mathrm{Log} \mathrm{W}=\log \mathrm{a}$ $+b \log \mathrm{L}$ (LeCren, 1951) where $\mathrm{W}=$ weight of fish, $\mathrm{L}=$ length of fish and $\mathrm{a} \& \mathrm{~b}=$ constants.

One-way analysis of variance (ANOVA) was used to determine the effect of sex and season in the length-weight relationship with the help of SPSS 10.0. Condition factor (K) known as fitness coefficient, was calculated as LeCrean (1951): K = (Wx100)/ $\mathrm{L}^{3}$, Where $\mathrm{K}=$ condition factor, $\mathrm{W}=$ total body weight $(\mathrm{g}), \mathrm{L}=$ total length $(\mathrm{cm})$.

\section{Results and Discussion}

The relationship between fish length and weight of the fish's body presents great importance in fisheries biology studies (Sparre et al., 1989) being used broadly with different purposes, namely to estimate the mean weight of fish based on a known length value (Beyer, 1987), to convert growth equations in length into the equivalent one in weight, to compare interspecific and intrapopulation morphometry and to determine the index of well-being of individual fish (Bolger and Connolly, 1989). In the present study brown trout (Salmo trutta fario L.) specimen collected from River Asiganga, ranged from 12.8 to $45.9 \mathrm{~cm}$ in male and 13.3 to $48.0 \mathrm{~cm}$ in female; while the weight was measured in between 20.61 to $1180 \mathrm{~g}$ in male and 24.37 to $1280 \mathrm{~g}$ in female. Earlier, Behnke (2002) reported that brown trout found in small streams of North America reached sizes of 25 to $30 \mathrm{~cm}$ and 227 to $340 \mathrm{~g}$, whereas those in rivers and lakes reached sizes of 35 to $76 \mathrm{~cm}$ and 0.45 to $5.4 \mathrm{~kg}$. Ozvarol et al. (2010) reported the longest and heaviest samples for brown trout from different streams of Turkey were $38.7 \mathrm{~cm}$ and $683.13 \mathrm{~g}$ for Kocun Bogazi stream, $22 \mathrm{~cm}$ and $110.4 \mathrm{~g}$ for Cenker stream, $23.3 \mathrm{~cm}$ and $153.12 \mathrm{~g}$ for Sirakonaklar stream. All these study showed the length and weight of brown trout (S. trutta fario L.) varied according to the habitat and altitude. The length and weight data were analyzed statistically to obtain their average values which were then subjected to regression analysis. Length-weight relationship equation were calculated as $\log \mathrm{W}=$ $0.310+3.096 \log \mathrm{L}$ for males; $\log \mathrm{W}=0.291+$ $3.040 \log \mathrm{L}$ for females and, $\log \mathrm{W}=0.302+$ 3.073 Log L overall. Seasonal length-weight equation was calculated as $\log \mathrm{W}=0.321+3.122$ $\log \mathrm{L}$ (monsoon); $\log \mathrm{W}=0.278+3.005 \log \mathrm{L}$ (winter); $\log \mathrm{W}=0.301+3.072 \log \mathrm{L}$ (spring); and $\log \mathrm{W}=0.308+3.091 \log \mathrm{L}$ (summer).The sex-wise regression coefficient was calculated 3.096 for the males $(r=0.958), 3.040$ for females $(r$ $=0.940)$ and 3.073 for overall $(r=0.985)$ (Fig. 2a $\&$ b). Season-wise, it was $3.122(\mathrm{r}=0.925)$ (monsoon); $3.072(\mathrm{r}=0.954)$ (winter); $3.005(\mathrm{r}=$ 0.956) (spring) and $3.091(\mathrm{r}=0.966)$ in summer (Fig. 3a-d). In the equation, the value of $b$ is greater for males, showing that the rate of growth in weight per unit growth in length is greater in males 
than in females. The $\mathbf{b}$ value in the length-weight relationship of fish can be used as an indicator of food intake and growth pattern and may differ according to such biotic and abiotic factors as water temperature, food availability, and habitat type (Wootton, 1992). When b is equal to 3 , it indicates that fish grows isometrically (Amin et al., 2008; Rahim et al., 2009). Tesch (1971) revealed that most fishes in aquatic ecosystem have $b$ values between 2 to 4 , and number of factor influence the length-weight relationship in fishes, including growth phase, season, degree of stomach fullness, gonad maturity, sex, size range etc. Froese (2006) recommended that the exponent (b) of lengthweight relationship should fall within the expected range of 2.5 to 3.5 . Based on the length-weight relationship of brown trout from Coruh Basin, Turkey Arslan et al. (2004) reported the b value of 2.97. Similarly, Ahmet et al. (2005) reported the value of exponent $\mathbf{b}$ in the length-weight relationship of Salmo trutta macrostigma as 2.971 for females and 3.009 for males in Firniz stream of the River Ceyhan, Turkey. Moreover, the lengthweight relationships for a single species of fish may differ substantially from one study to the next Kimmerer et al. (2005). The value of $\mathbf{b}$ differ not only between species but sometimes also between the stock of the same species due to sex, maturity, seasons and even time of day because of changes in stomach fullness (Bagenal, 1978). The one-way analysis of variance (ANOVA) was calculated seasonally between length and weight for different sexes of brown trout inhabited in River Asiganga and presented in Table 1. There was no significant difference in terms of body length $(\mathrm{F}=0.03, \mathrm{P}=$ 0.86 , $\mathrm{df}=1,251)$ and body weight $(\mathrm{F}=0.29, \mathrm{P}=$ 0.59 , df $=1,251$ ) of both the sexes. However, analysis of variance indicated that length-weight relationship varied seasonally. The highly significant relationship was between length $(\mathrm{F}=$ $10.39, \mathrm{P}=<0.0001, \mathrm{df}=3,249)$ and weight $(\mathrm{F}=$ $9.49, \mathrm{P}=<0.0001, \mathrm{df}=3,249)$. The value of condition factor $(\mathrm{K})$ was calculated for each fish and the average monthly $\mathrm{K}$ value for different sexes is depicted in Table 2. The maximum value was recorded, i.e., $1.451 \pm 0.419$ and $1.430 \pm 0.203$, respectively for male and female. While seasonally it was maximum during winter being $1.473 \pm 0.694$ and $1.357 \pm 0.210$ for male and female respectively (Table 3). Kumar et al. (1979) reported ponderal index $(K)$ in the streams of Kashmir in the range of 1.19-1.31 and highest values of $\mathrm{K}$ were registered both for males and females in October. LeCrean (1951) maintained that the condition factor is affected by length as well as several other factors like environment, food supply and degree of parasitism.

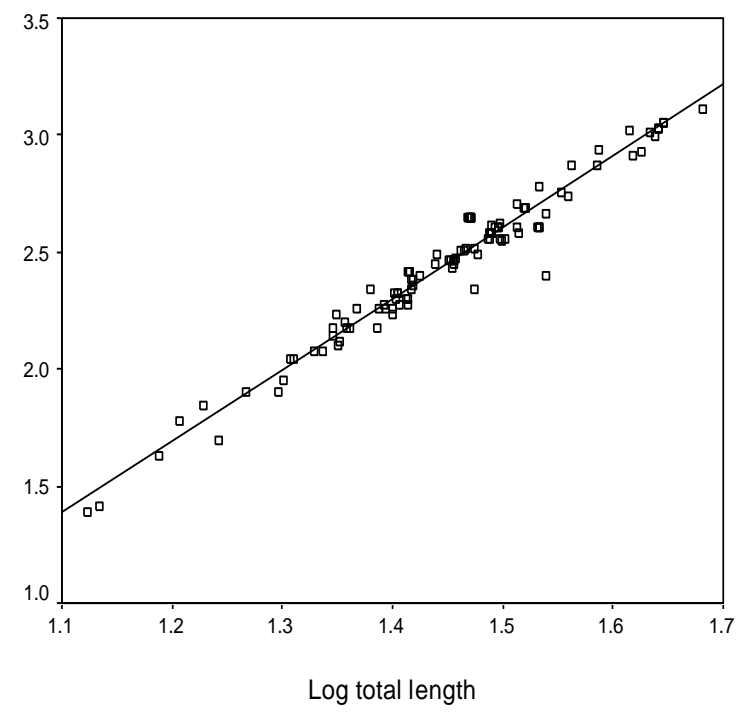

a) Male

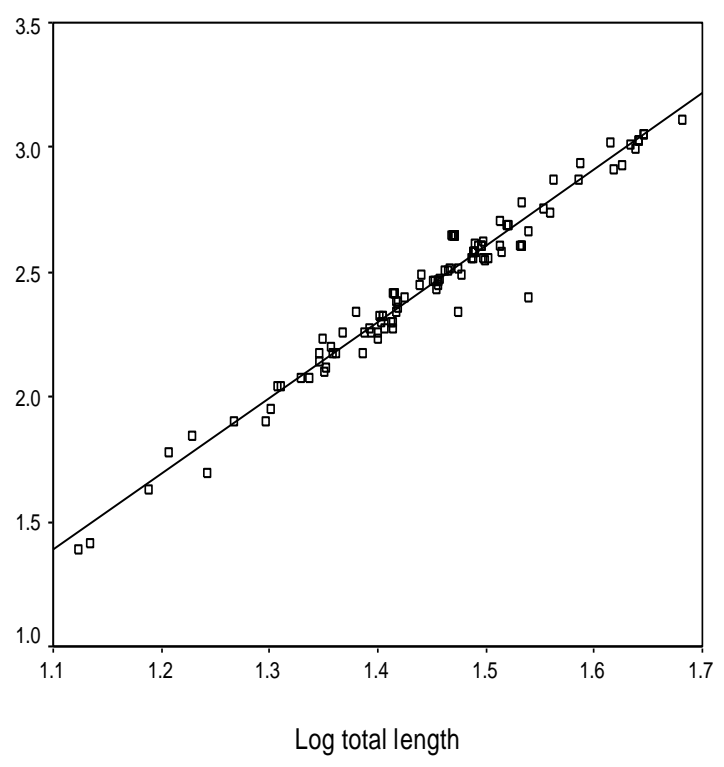

b) Female

Fig. 2. Length-weight relationship in male and female S. trutta fario $\mathrm{L}$. 
Rawat et al.

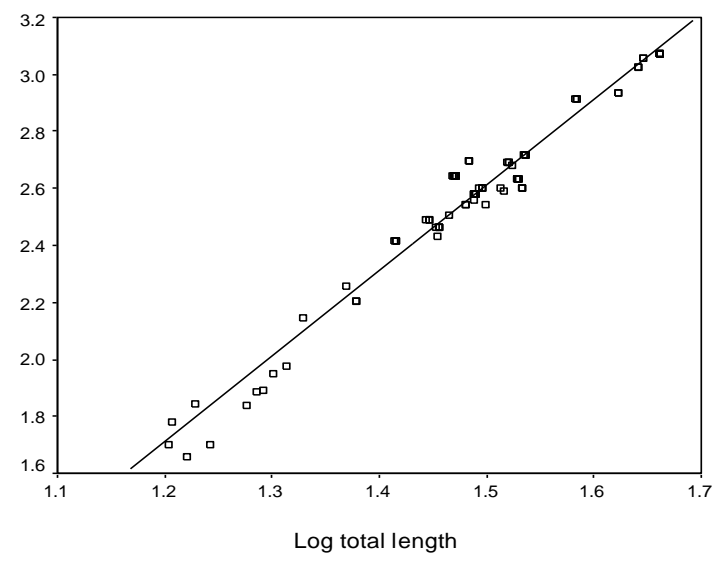

a) Winter

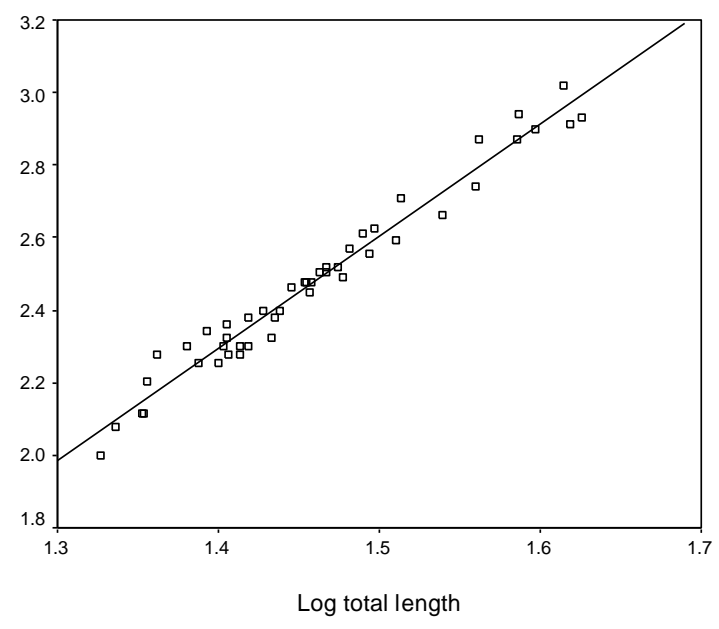

c) Summer

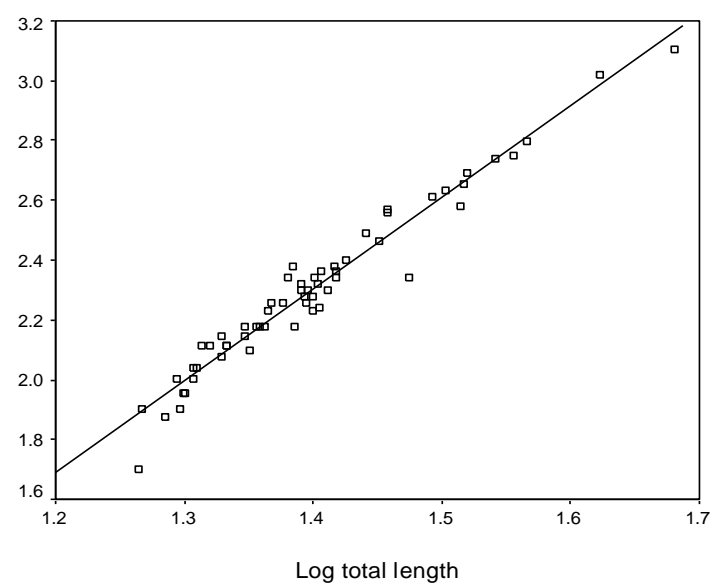

d) Spring

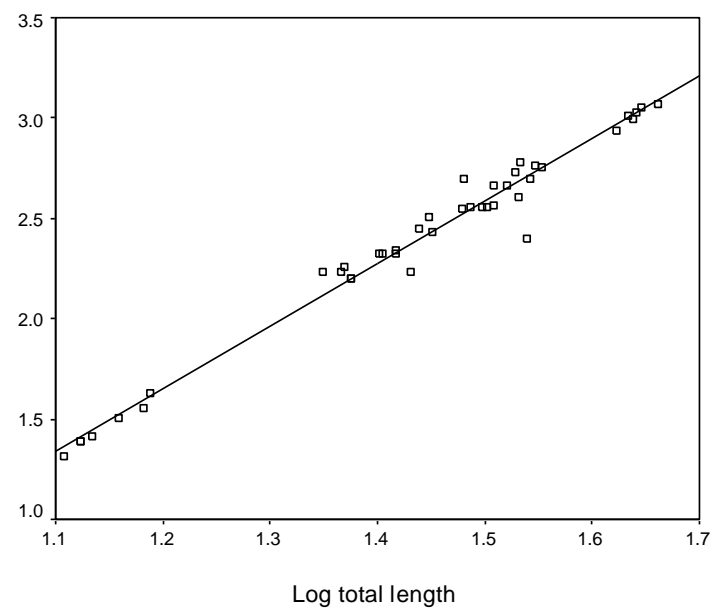

e) Monsoon

Figure 3 (a-d). Length-weight relationship of $S$. trutta fario L. during different seasons

Table 1. One way ANOVA (analysis of variance) between sex and season

\begin{tabular}{lllll}
\hline Sex & df & F value & P & \\
Length & 1,251 & 0.03 & 0.86 & NS \\
Weight & 1,251 & 0.29 & 0.59 & NS \\
Season & & & & \\
Length & 3,249 & 10.39 & 0.0001 & S \\
Weight & 3,249 & 9.49 & 0.0001 & S \\
\hline
\end{tabular}

S=Significant, $\mathbf{N S}=$ not significant 
Length-weight relationship and condition factor of brown trout

Table 2. Monthly variation in the condition factor $(\mathrm{K})$ of male and female $S$. trutta fario $\mathbf{L}$

\begin{tabular}{lcc}
\hline Months & Male & Female \\
\hline Aug. & $1.242 \pm 0.075$ & $1.290 \pm 0.091$ \\
Sep. & $1.262 \pm 0.126$ & $1.295 \pm 0.163$ \\
Oct. & $1.298 \pm 0.115$ & $1.294 \pm 0.072$ \\
Nov. & $1.332 \pm 0.099$ & $1.306 \pm 0.080$ \\
Dec. & $1.429 \pm 0.247$ & $1.370 \pm 0.370$ \\
Jan. & $1.451 \pm 0.419$ & $1.430 \pm 0.203$ \\
Feb. & $1.107 \pm 0.547$ & $1.156 \pm 0.125$ \\
Mar. & $1.126 \pm 0.291$ & $1.193 \pm 0.196$ \\
Apr. & $1.157 \pm 0.352$ & $1.198 \pm 0.247$ \\
May & $1.197 \pm 0.151$ & $1.222 \pm 0.178$ \\
Jun. & $1.217 \pm 0.093$ & $1.261 \pm 0.132$ \\
Jul. & $1.232 \pm 0.282$ & $1.264 \pm 0.131$ \\
\hline
\end{tabular}

Table 3. Seasonal variation in condition factor $(\mathrm{K})$ of male and femaleS. Trutta fario $\mathrm{L}$

\begin{tabular}{lcc}
\hline Season & Male & Female \\
\hline Winter & $1.473 \pm 0.694$ & $1.357 \pm 0.210$ \\
Spring & $1.269 \pm 0.274$ & $1.237 \pm 0.157$ \\
Summer & $1.188 \pm 0.282$ & $1.263 \pm 0.129$ \\
Monsoon & $1.213 \pm 0.223$ & $1.208 \pm 0.202$ \\
\hline
\end{tabular}

This factor varies according to influences of physiologic factors, fluctuating according to different stages of the development. During the present investigation the maximum condition factor values for male and female $S$. trutta fario $\mathrm{L}$. were observed as 1.451 and 1.430 , and minimum values observed were 1.107 for male and 1.156 for female respectively. The condition factor when calculated seasonally, showed highest values during winter (spawning season). The high value of condition factor during winter in both the sexes was ascertained due to great increase in the gonadal weight during this period. Isaac-Nanum and Vazzoler (1983) also reported the condition factor as indicator of the period of spawning.

\section{Acknowledgement}

Authors are thankful to U.G.C., New Delhi for financial assistance in the form of major research project F. No. 34-434/2008(SR).

\section{References}

Ahmet, A., Kara, C. and Murat, H., 2005. Age, growth and diet composition of the resident brown trout, Salmo trutta macrostigma Dumeril 1858, in Firniz stream of the river Ceyhan, Turkey. Turk. J. Vet. Anim. Sci., 29: 285-295.

Amin, S.M.N., Zafar, M. and Halim, A., 2008. Age, growth, mortality and population structure of the oyster, Crassostre amadrasensis, in the Moheskhali channel (Southeastern coast of Bangledesh). J. Applied Ichthyol., 24: 18-25.

Arslan, M., Yildirim, A. and Bekta, S., 2004. Length-weight relationship of brown trout, Salmo trutta L., inhabiting Kan stream, Coruh basin, north-eastern Turkey.Turk. J. Fish. Aquat. Sci., 4: 45-48.

Bagenal, T.B., 1978. Methods for Assessment of Fish Production in Freshwaters. Third Ed. Black well scientific publication, Oxford, London, 365p.

Behnke, R.J., 2002. Trout and Salmon of North America.First edition. The Free Press, Simon and Schuster Inc., New York, $360 \mathrm{p}$.

Beyer, J.E., 1987. On length-weight relationships. Part I: Computing the mean weight of the fish of a given length class. Fish Byte., 5: 11-13.

Bolger, T. and Connolly, P.L., 1989. Selection of suitable indices for the measurement and analysis of fish condition. J. Fish Biol., 34: 171-182. 


\section{Rawat et al.}

Froese, R., 2006. Cube law, condition factor and weight-length relationships: History, meta-analysis and recommendations. J. Appl. Ichthyol., 22: 241-253.

Goncalves, J.M.S., Bentes, L., Lino, P.G., Ribeiro, J., Canario, A.V.M. and Erzini, K., 1997. Weight-length relationships for selected fish species of the small-scale demersal fisheries of the south and south-west coast of Portugal. Fish. Res., 30: 253-256.

Isaac-Nahum, V.J. and Vazzoler, A.E.A. de M., 1983 .Biologia reproductive de Micropogoria sfurnieri (desmarest, 1823) (Teleostei, Sciaenidae).Fator de condicao como indicador do Periodo de desova. Boletim do Instituto Ocenogrefica, Sao Paulo, 32 (1): 63-69.

Kimmerer, W., Avent, S.R. and Bollens, S.M., 2005. Variability in Length-weight relationships used to estimate biomass of estuarine fish from survey data. Trans. Am. Fish. Soc., 134: 481-495.

King, M., 1995. Fisheries biology, Assessment and Management: Fishing news books. First Edition. Blackwell scientific Ltd., Oxford, 340-341.

Kumar, K., Sehgal, K.L. and Sunder, S., 1979. Length-weight relationship and ponderal index of brown trout, Salmotruttafario (Linnaeus) catches in the streams of Kashmir. J. Inland Fish. Soc. India, 11(1): 56-61

Lawson, E.O., 2011. Lenth-weight relationships and fecundity estimates in mudskipper, Periophthalmus papilio (Bloch and Schneider 1801) caught from the mangrove swamps of Lagos Lagoon, Nigeria. J. Fish. Aquat. Sci., 6: 264-271.

LeCren, E.D., 1951. The length weight relationship and seasonal cycle in gonad weight and condition in perch (Perca fluviatilis).J. Anim. Ecol., 20: 201-219.

Morey, G., Moranta, J., Massuti, E., Grau, A., Linde, M., Riera, F. and Morales-Nin, B., 2003.Weight-length relationships of littoral to lower slope fishes from the western mediterranean.Fisher. Res., 62: 89-96.
Moss, B., 1998. Ecology of Freshwaters: Man and Medium, Past to Future. Third Edition, Blackwell Science Ltd.

Nikolsky, G.W., 1963. The Ecology of fishes. First edition. Academic Press, London and New York, 352.

Ozvarol, Z.A.B., Yildirim, A., Bektas, S., Ozvarol, Y. and Yilmaz, S., 2010. Intrabasin variation in growth and condition of brown trout (Salmo trutta) inhabited Coruh basin, Turkey. J. Anim. Vet.Adv., 9(19): 2445-2454.

Pauly, D., 1993.Fish byte section editorial, Naga. First edition, ICLARM Quart.16-26.

Rahim, M.H.A., Rozila, A. and Mat Jais, A.M., 2009. The physicochemical and morphological study of haruan Channa striatus in Peninsular Malaysia. Res. Biol. Sci., 4: 994-1009.

Rawat, M.S., Bantwan, B., Singh D. and Gusain, O.P., 2011.Status of brown trout (Salmo trutta fari L .) in Garhwal Himalaya with a note on it morphometric characteristics. Env. Cons. J., 12(3): 47-52.

Richter, H.C., Luckstadt, C., Focken, U. and Becker, K., 2000. An improve procedure to assess fish condition on the basis of length-weight relationships. Arch. Fish. Mar. Res., 48: 255-264.

Sparre, P., Ursin, E. and Venema, S.C., 1989. Introduction to tropical fish stock assessment. Part I - Manual. FAO Fisheries technical paper, No. 306.I Rome, FAO.

Tesch, F.W., 1971. Age and Growth in Fish Production in Fresh Waters. Blackwell Publisher, Oxford, 98-130.

S.P.S.S., 1999. Advance Models 10.0 S.P.S.S. Incorporation, Chicago, IL. 60606-6307.

Wootton, R.S., 1992. Fish Ecology. First edition., Great Britain by Thomson Litho Ltd., Scotland, 203p. 